\title{
Women Participation in Politics: A Case Study of Afghan Women
}

\author{
Muhammad Ibrahim (Ph.D Scholar) \\ Lecturer Govt. Postgraduate College Bahawal Nagar \\ Email: prof.ibrahim69@yahoo.com
}

Professor Dr. Razia Mussarat

Chairperson, Department of Political Science, Islamia University Bahawalpur

Doi:10.5296/ jpag.v4i3.7190 URL: http://dx.doi.org/10.5296/ jpag.v4i3.7190

\begin{abstract}
Women are awarded minimized role in politics. Political activities are considered the special domain for men. Women are stressed that home is predominant place. The major role related for women is reproduction of human race. The objectives of the study are to discuss concept of political participation and its objectives for women participation in politics. The central aim is to examine the empowerment of women particularly of Afghanistan. The paper focuses on present contribution of afghan women in presidential election of Afghanistan in 2014. The process includes the voice of Afghan women for successful outcome in election 2014. The empirical and analytical analyses have been adapted to forecasting the present status of afghan women by empowering their right not only by casting a vote rather by full political participation. The under discussion issue is voter turn-out after huge participation of women in presidential election. The study will analyse structural causes and customs which limit women opting to pursue elected offices and member of loyia Jirga. The future prospects for Afghan women participation in politics.
\end{abstract}

Keywords: Women participation, Afghan women, Jirga system 


\section{Introduction}

There will be expectation of free and fair election for selection of future leadership. The afghan women have to participate in electoral process. It is critical test for administration to secure the right of female voters which is rolled back. The process of securing polling stations are underway because severe threats against female voters of Afghanistan. The significant progress is needed for security purpose to secure polling stations as well as polling staff. Otherwise it could sensationally limit the prospect for females in casting vote. Electronic and print media, nongovernmental groups as well as civil society are working to meet the issue of voter turnout. To enhance turnout women participation is requisite in electoral process. The shortage of security staff has impact on ratio of female casting votes. The two time presidential elections held since 2014 election. Different types of measures can helpful in promoting women participation in democratic process. These outcomes are fruitful in present and next coming elections. There is need of platform which advocate for equitable electoral reforms. The election commission has to work with organizations of Afghan women to promote network building for contribution of women participation and lesson sharing among female parliamentarians and potential candidates. The concept of participation, Shift in Afghan women rights after 9/11, Challenges to Afghan women's for Political Participation and political participation model is included in the study.

\section{Literature Review}

Laura Grenfell discusses the status of women in the socio political and cultural sphere in her article. Although women have any significant position in the afghan community but women raised their voices and contribute in reconstruction and progress of the country. Civil activist women along internal organizations gradually protect their rights by preventing them from violation. Palwasha Kakar (2014), being a civil activist promoting afghan women political participation in recent presidential election. She also tries to engage the religious elders and tribal elders to ensure the women rights and protection. Oxfam briefing paper (2011), explain the afghan women situation during the rule of Taliban. Their merciless policies regarding the socio political sphere of the women deprive them from their fundamental right as the citizen of the country, then Author discussing such policies and strategies which safeguarding the women's rights.

Frud Behzan (2013) discussing the women movement which came in to scene in Afghanistan as a revolution to ensure their rights and recognition in the society. She also discussed those female civil activists like Kofi and Amina determined to fight against gender discrimination. Farzana Bari (2005), in her draft discussed the general status of women in the world. She also explained the multiple challenges in expressing ideological factor, economic, political, and social perspective. Capability of afghan Women's got underwent as the result of hardship which they faces due to impartial policies from the government.

Sara Van wie,(March 2014 explained the legal rights of the women of Afghanistan) in her paper. She also discussed the active and massive participation of the afghan women in their elections of 2009-2010, and in recent 2014 became a reason for the successful transition of country. Jan Teorell (2006) explains the basic concept of political participation. He also 
discussed different models and theories regarding the citizenship right for both men and women of country. Maria Ermenko in her paper clears the concept of political participation through quoting the basic definition of verba. She also explained methods of political participation of three countries by using the verba model of verbal regarding political participation.

Nina and Scott, (2010) discuss the challenges for Afghan women in past and present elections. They discuss the trend of proxy voting which is common in Afghanistan due to absence of women's picture in their id card. Clara Morgan (2008) defined the status and duties of Afghan women after establishment of first afghan democratic government. The author also discussed those points which mark the challenges for afghan women for example lack of access of education and discrimination against women gender. Open Society Institute made a report on the political participation of afghan women by a survey. A civil activist and a female lawyer contributed to wind up this report from their survey. They describe the status of afghan women and their lives since ancient time.

Nahid Afrose Kabir (2012) discusses about awareness of women's rights in Afghanistan after 9/11. It observed that with the intervention of global communities particularly the USA contributed a lot to strengthening the afghan women's position in her community. Dr. Huma Ahmed-Ghosh (2003) in a splendid manner defines the historical aspect of the Afghanistan women. She also discusses the present and future of the afghan women in their political life on the behalf of their ideological and cultural values. Margherita (2014 April) discussed the role of women also demanding their right of citizenship in political participation will may empower the women's status not only in their community rather for the rest of the world.

\section{Concept of Political Participation}

The classical theorists as Verba and Nie state as "The political participation refers to those activities conducted by private citizens that... aim at influencing the government, either by affecting the choices of government personnel or by affecting the choices made by government personnel."'The political social scientists explained about participation as it is influential act through which people made an effort to make response according to their will for the political system. It is explained according to philosophy of participation by Verba, "Participation is a means the leading representatives cognizant about the preferences, priorities and basic needs of the masses which are persuaded to respond to public wishes".(Teorell, 2006, pp. 788-89)

The social scientists have work on women political participation. The scholars have considered that political participation of women is a significant factor in democratization. It is fundamental success for women. For the success of any country the model of democracy is essential. The word democracy is not coined for males.(International Declaration of Democracy in1997). The basic principle of democracy defined as, "Access of democracy includes the significant participation of men and women in the social and political affairs based on the equality to complement each other and to profit from one another and to profit from another's differences."'(N.A, 2005, p. 19) 


\section{Macrothink}

Journal of Public Administration and Governance

ISSN 2161-7104

2014, Vol. 4, No. 3

The process of democratization developed civil society because democratic process offers the requisite terms and conditions for democratic institutions. These democratic institutions enhance political participation of public. The political system of democratic state based on four basic principles: the public participation in democratic process. It means that men and women are equally participating in their political activities for the wellbeing of the state. Another explicit definition of political participation is, "It affords citizens in a democracy as an opportunity to communicate information to government officials about their concerns and preferences and to put pressure on them to respond." It is observed in American politics that widespread expression of public views for political participation is mostly voluntary basis. Americans political leaders having taken parts in politics are active. Among different political acts of citizens in political participation one of them is most remarkable is voting. The use of ballot paper to vote is the easier technique for participation in political activities. It is not just in the form of declarative rather everything is implemented in practise. Americans contribute in political participation due to their possibilities, resources and skills. According to Sydney Verba "The Americans political participation act reflects one important feature of political life in states- freedom of choice."(Eremenko, pp. 1-4)

In European political system political participation means, it is assumed to connect with representative bodies like European Parliament, European Council and Council of Ministries. The national parliament made accountability of these elected bodies that was voted by public. The process is written in the constitution EU. These apparatuses provide opportunities to masses the right of participation in democratic life of Europe Union. Sense of participation means here actual participation in vote. Hence all form of political participation of citizens should participate at nation-state level not at the level of Europe Union. The most appropriate method to contribute in democratization of Europe Union which based on participation in elections and referendum.(Eremenko, pp. 2-5)

\section{Model of Political Participation}

The political participation has developed most important subfield of political science. There are different models of political participation in democratization such as; responsive, participatory and deliberative model of participation.

Due to process of political participation, the political system response to needs and preferences of the participants termed as the populist democracy and author termed it as responsive model of democracy. Dahl's an approach to understudy democracy to political system having the characteristic of quality to responsive to all its citizens completely or almost completely. Dahl's and Downs views such attention will paid as in the result of competition of parties in general election means to bring about responsiveness. The participation is measured as an indirect action or the policies outcome of authorities. According to Barber's; "Politics in the participatory mode...is self-government by citizens rather than representative government". The meaning of participation is the direct involvement of the participants and their influence upon decision makers. The participatory model followers have opinion that participation means involvement in process of decisions making. This explanation should not sufficient to abolish all representative institutions, other 
than traditional representative mechanism way which sort way have been suggested by theorist for direct participation in politics. Pateman stated in defence of the participatory model that entirely deals to decision makers at the work places. As the result another theorist Gould argued that local participatory institutions have power to deal local concerns. The main purpose behind the huge participation of the masses remains to solve the community problem within the framework of participatory democratic model.

According to theorist of deliberative model of democracy what should be count as deliberation for political participation. The deliberation is obligatory as collective or individually carried out and focusing on reasons with urgings in an intellectual dialogue. Deliberation is the process of decisions making for establishing opinions of individual. Elster define it as, "deliberation means as decision making by means of arguments." Deliberation is as a political discussion about political system. The discussion aimed to developing opinions may follow even there is no consensus based decision gotten. According to Fearon, "I deliberated on the matter. I discussed the matter with myself". It is considered that participation is activity which means to engage in some kind of combined effort.To define the meaning of deliberation is more vivid as debate is more appropriate about the concept of participation. The deliberation is related to concept of participation. It means we can elude blurring in separating deliberative and participatory models of democracy. It provides more chances to take participation in the political discussion. (Teorell, 2006, pp. 789-791)

Historically democracy has served better than women. From ancient Greece to contemporary period twenty first century, exclude women from the sphere of participation on the basis of public and private dichotomy. Plato, Aristotle, Rousseau, John Lock, Thomas and Hegel considered women have a role for domestic activities so that the majority of women are kept out of the public affairs. Many historian and political philosophers are in favour of women role in cloistered domain. According to their approach there is no place for women in political domain because of their significant role as mother and wives. That's why the public-private division remains as the foundation for various practices in the democracies of the world.(Bari, 2005, p. 4)

\section{Right Origin of Political Citizenship of women}

Approximately $96 \%$ of women in the world have right to vote and holding public offices from period of 1890-1994. The right of universal suffrage already exists both in an institutionalized form. It is in the form of core element of an incorporative model of political citizenship. Due to contradiction in the basis of gender boundaries between the public domain and in the familial domain, these reasons lead and provide base of women's franchise movement. The struggle for women's suffrage is considered an international crusade drawing on the bases of universalistic principles. The unintended consequences of continuous social movements enhanced the status of citizenship. The acquiring right of franchise in the earlier period has helped to foster more receptive political structure and stronger women's social movements. The wave of women suffrage began in 1893 in New Zealand likely growing in other parts of the world like right of suffrage extended in 1902 in Australia. According to author in 1900, women had gained the franchise in less than one \% of the world as compared 
with some $18 \%$ for men. Later it is prolong to European states to increase the women rights of political participation till 1930.

The women franchise movement get accelerated in the development of decolonization in 1930s to1980s. In this era majority of countries of the world possessed the legal rights to activate in politics for women. There are some countries has not fully extended the rights of suffrage to men and women. It is hard task yet to acquire voting rights on adult suffrage in Qatar, Oman, Saudi Arabia, UAE and Kuwait. The movement of political participation and right to vote for women proliferated for both men and women in the twentieth century. It made the gap narrow between the numbers of countries with male and female suffrage. Having the universal franchise gap is narrow between different countries with the passage of time. During the age only Australia, Libya and Ireland extended suffrage the right of suffrage to men prior to women. It is studied that in France adult suffrage give to men in 1875 but as for concern for, women should have to wait for a long time almost for 69 years till 1948 . Similarly is the case for other countries as it is in Swiss government have given the right of vote to women in 1971. Here are male get right of vote in 1848 the gap between gender discrimination regarding this right almost 123 years.(Francisco O. Ramirez, 1997, pp. 735-738)

\section{A Case Study of Afghanistan Women}

The political status of women in Afghanistan has customarily been lesser to the men. The status dramatically changes with the passage of time in terms of socio cultural, norm and upon ethnic values.(Rahimi, 1991, p. 6)It is pointed in many societies and communities where women focus the challenges which faces women's during their participation in politics. Some other critics argue, "women's have no capacity and capability to take over some political and social responsibilities, which in itself have been a big obstacle in their way to have equal participation in the arena of socio-political".(N.A, 2005, p. 7)

The population of women is more than half of total population of the world. The women have a great contribution and collaboration in social and economic development of societies. The performance of women is twice in comparison of males due to twofold roles of productive and reproductive circle. In the contemporary era contribution of women in the legislation process in world is nearly fifteen percent. Farzana Bari reports about representation of women in different states. It is states that there are twelve countries where women hold approximately $33 \%$ seats in the parliaments. There are different ways and means that can fruitful in promotion of women's political representation of women in different elected bodies. The internal and external conditions and factors are identified. These factors facilitate in development of such environment where women have political empowerment.(Bari, 2005, pp. 1-2) The situation of women used as to symbolize to western military powers a justification of war at the stance of freedom of women. As the result the present situation of afghan women is not the product of the policies of Taliban. There is the history over the centuries of women's subjugation.(Ahmed-Ghosh, 2003, p. 2)

From different survey reports from Afghanistan territories like, Badakhan, Qora, Demracy, Sistan and etc., tend to help us to find out the traces of presence of women's political 
activities through the history of Afghan territory. It is too difficult to search out their secrets of life in politics. The social and political role of women is during the circumstances of emergency and matriarchy in country. Meanwhile the contribution of afghan women in the social and political matters in dynasty of Wida the biggest evidence is in their chansons. The chansons share knowledge about different classes with social structures and other discriminations o in this period. The wida chanson is related to honour and appraisal about equivalence of males and females in family and public. The presence of women has been substantial in local consultancy. It describes about the status of women which were welcomed to the meetings of community where decisions were made for their community. Men and women shared together in singing chansons. All other customs of society as animals sacrificial and worship performed together.

During the era of Avesta the participation of women can be realized from historical facts. Women are participated in their social and cultural affairs in this age as well as responsible for the credibility in their family. Avesta community is denying from marriages considered a blot, "Parents were the wooers of marriage, but the satisfaction of couples was also essential, it symbolizes the equality of men and women in terms of their right which did not recognize the present unfair traditions and customs. The status of women in Afghanistan after Islam, during seventh century women ever had a social significance that was never obtained during the following centuries".(Rahimi, 1991, p. 6) According to the law of that time women's had the right to seize the throne. There are inside clashes and riots based on anti-Arabs emotions which get defeated. These failures have deep impact on women status. The women become helpless in their way to achievements in life. These messed up their normal social life as well. The invasion of Mongolians devastated economic, social and cultural foundation of this region in thirteen century. The common people are massacred. The libraries and schools are ruined woefully. At that time not only women rather whole nation had to fight for their lives and had to provide the Mongolian troops with their requirements. As result of encouragement and insistence of the Gohar Shad Begum from her struggle Herat was once more revived and renovated. Moreover still in the twentieth century the women of Afghanistan were the slaves of their husband, father-in-law also under brother law. One of the most valued characteristic was silence and obedience.(Bari, 2005, pp. 21-26)

In the history of Afghanistan during the period of Amir Habibullah, women are assigned a role which is related to activities outsidethe home. A prominent Afghan woman Mahmood Beg Tarzi resisted over protective restrictions on women. It is debated that Islam is never in denialin women right of education in community. Islam provides opportunities to women for social functioning in society. Many reforms are implemented in Afghanistan in different eras of its ruler. The coeducation schools are established in the period of Amanullah's government. Next Afghan Youth Organization is established for the resolutions of their problems. It is the first time in Afghanistan a hospital was founded for cure of women. The sense of awareness about women for their rights evoke through a newspaper named as Irshadun-nisa. In his government the veil of the women has been abolished and their living conditions were also raised. With the fall of king Amanullah government above mention significant reforms of women's were banned. After the Second World War the question of 
women's education raised at international forum along with the establishment of "Women's Welfare Association" by the Ministry of Kabul in 1946.(Rahimi, 1991, pp. 15-16)

It is comprehensive debate on the objectives of promotion of political representation of females have been surrounded in intrinsic and instrumentalist manner in the $21^{\text {st }}$ century. According to human rights perspective many scholars argue and demand the right of equality for women to participate in politics. They demanded to have equal chances to participate and represent in world democracies. According to Leacock why women's remain deprive from their right of participation as he stating that, “... the inequalities between men and women could not be understood in isolation from polarizing tendencies of the capitalist mode of production which places the peripheral countries of the third world in a relationship of dependency with the metropolitan canters. Within egalitarian world order, so called development could not release women from oppressive social, economic and political institutions; it merely defines new conditions of constrains.”(Bari, 2005, pp. 1-2)

\section{Afghan women's rights Shift after9/11}

Since 2001 Afghanistan women have got share in political activities with political participation. The women have taken part in implementation of rule of law. They are performing very well in field of education. These hard won gains remain fragile still in Afghanistan. Women political activities are raised after withdrawal of US led NATO forces form Afghanistan. It is felt fear that there is a risk which be taken in government's deal with Taliban. There is a chance to abolish the women rights in order to secure a political stability in Afghanistan. It is pre requisite to settle down issues with armed groups for political stability. The government and its international allies have to pay attention to effort of Afghan women for upholding of their right. It is making ensure that Afghanistan women have strong voice in future for negotiations and political settlement.(N.A, 2011 p.7)

The right to cast vote has been given to Afghan women in 1342 Hijri during period of Mohammad Zahir.(Manger, 2014)Later that, women has to face many challenges about the right to vote from 1964.In afghan society women has been an active participant of political activities. Before the Taliban rule seventy\% of Afghanistan women are teachers and forty $\%$ among doctors are female. Many of females are engineers, architects, lawyers and judges. As result of wars, the sources of income of many families convert to income of women. Afghan women remained deprive from their fundamental rights in era of Taliban. Taliban bane to seek on any kind of education for them, from kindergarten through graduate school, either talking or walking loudly in public "women you should not step outside your residence".(Palmerless, 2002, pp. 2-3)

The former president George W. Bush of America had indicated that we have a great chance in this war which is against terrorism to lead world. This war leads towards such values that will bring long-term peace... We have no intents to impose culture on other communities. Moreover America will always stand firm for the non-negotiable demands for human dignity mostly respect for women. The secretary of USA stated on occasion of international women day for basic rights of women which linked to prosperity and peace in world. The stable governance cannot exist in long time all those societies where women are deprived from their 
basic human rights. An agreement signed by the Afghan representatives in Bonn December 2001, underscored the centrality of democratic principles and human rights also includes protection of women rights. It also provided for the Afghan interim Authority to govern until the establishment of a transitional Administration by a traditional Grand Council also known as a Loya Jirga with the strong encouragement of the USA, two women were appointed to the Afghan Interim Authority.(Palmerless, 2002, pp. 2-4)

The article III of the Bonn agreements stated that delegates designated members of the Interim Administration "with due regard to... the importance of the participation of women." The objective of this settlement remained to create a broad based, gender-sensitive, multi-ethnic and fully representative government" by 2004.Its responsibility is to promote possibility of women participation in the field of politics. The first democratic election held in 2004 and 2005 in which hundreds of thousands of women's participated to cast their vote out of 10.5 million Afghan. Due to poor law and order situation the security remained fragile during this period which threatened them to keep out them from political participation. The bomb is blasted in a passenger bus in late 2004. Due to blast two afghan women has died and many of others wounded. The bus is carrying female staffs which are concern to registration work of election in Jalalabad. There is another way to prevent the afghan women from using the right of citizen's partnership which can be realized from the past deeds of the Afghans. For example in the election of 2004 a female candidate Masooda Jala stood against 17 male competitors. However she was prevented from speaking and campaigning at various places. (Grenfell, pp. 23-24)

After the incident of 11 September 2001, tend to argue that on October 7, 2011 US-led occupation of Kabul the position of women in Afghanistan has improved. The huge numbers of girls are attending schools and women's are participating in politics, entertainments and sports. Fawzia Koofi became a member of parliament in 2005 also elected as a first deputy speaker in parliament of the country in 2005-2006. Another women Robina Muqimyar afghan athlete is running for parliament and wishes to establish a sport ministry. In 2010 an- other afghan women contributed for the betterment of afghan females, a Canadian-Afghan refugee woman name Mozhdah Jamalazadah hosted an Oprah style talk show which promoted women's rights without any hesitation. According to article 83 of the constitution of Afghanistan $25 \%$ female can occupy representation in parliament. Many scholars argued that "Afghan is expected to take responsibility for their own security on 31 December 2014."(Kabir, 2012, pp. 1-2) As the result it is more convenient for Afghan governments should adapt such policies which further strengthen the status of afghan women in socio cultural and political life. Afghanistan for the protection of women's right and freedom with global community acceded with CEDAW (Convention on the Elimination and Discrimination against Women) on March 2003, made a framework to ensuring women's full political participation. CEDAW a binding multilateral treaty requires that women be granted equal participation to men in the field of politics.(Grenfell, p. 22)

The national assembly of Afghanistan comprises upon two houses the house of Wolesi Jirga and Meshrano Jirga. So according to article 84 of the Afghan constitution which guarantee them that almost $17 \%$ women having seat in the Meshrano Jirga and allocating minimum 
$25 \%$ seats in the Wolesi Jirga. The objectives behind the above mention changes have target to attain equivalence in representation of women which take part in formal decision making process. Some challenged status quo situation because of those who participated in governing issues. But it not necessarily replicates extent of decision making power or influence. Mulalai Joya a female from the Afghanistan province of Farah an elected parliamentarian overthrown from lower house (Wolesi Jirga) in May 2006 through critiquing by colleague, one might be that reason that in 2003 she had vocalized out openly against warlords involved in drafting the Afghan constitution. It is accused by many scholars that not only Taliban's rather internal warlords and their proposed policies considering a great threat to women's status.(Morgan, 2008, p. 3)

The only women Habiba Sarabi is running on a political ticket general elections in April 2014. At that time the former governor of Bamiyan who is now allied with Zalmai Rassoul vying to become Afghanistan first vice president. Her inclusion is likely to pull out women to polling stations on the day of election, and will also strengthen the Rassoul-Qayuum alliance. (Fahd, 2014, p. 9)Afghan women are taking interest in political activities which can be seen at a polling station of Mazar-i-Sharif. A woman is waiting in line to cast her vote on April 5, 2014 which will mark the first democratic election of Afghanistan. (Donati, N.A, p. 2)According to the national Electoral Commission of Afghanistan women made up to 34\% of those voting. That is why Afghan and western leaders have described Afghanistan's presidential election and the turn out as a success. William Hague the foreign secretary of UK stated that it is a great realisation from the masses Afghanistan. It is observed male and female casted their votes without discrimination of age whether young or old. They have turned out despite terrorizations of violence in such a large numbers for democratization and future of country. Mr Rasmussen applauds the millions men and women of Afghanistan from across the country. They have cast their votes with enthusiasm in presidential and provincial council elections with such an extraordinary turnout. The Chief of Election Commission stated that this election was a vibrant message to enemies of Afghanistan and with this solid determination of Afghan people, enemies were defeated.(N.A, 2014, pp. 3-6)

The political analyst stated Afghan presidential election is turning out to be a tale of two narratives. The more positive and democratic one could be winning the day. It is explained by IPS's Guiliano Battiston and quotes from one of Martine Van Bijlert's. All it will possible the only reason which facilitates its success remains the massive participation of the voters in the Afghan 2014 elections, approximately the voter turnout will gradually raise the graph of the elections results compare to earlier elections.(Thomas-rutting, 2014, p. 1)

It is argued by many scholars that the situation of security will determine voter turnout, especially in southern and eastern provinces and women participation will be most at risk if security cannot be provided. That is why international security forces provided support on the day of political contests in the country national security forces for a secure environment. In order to ensure a peaceful transition presently armed opposition groups should participate in the electoral process if they meet basic redlines, renouncing violence and respecting the afghan constitution.(N.A, 2013, pp. 1-2) 
The afghan women have deeply expressed with their firm determination for cast ballot paper in the presidential elections. In this way they mark the fortune of country with their own hands by cast vote for better future of next coming generations. These women have believe about extended political participation in the election which strengthen the credibility and legitimacy of elections. It supports the restoration of long-standing peace and security of the country with the help of democratic process. (Manager, 2014)

After the evacuation of American troops from Afghanistan, in next the coming years with the new leadership have significant role for the development and progress of the country. As the result main agenda put in front of religious leaders who are basically gate keepers of the country have to strengthen the fundamental rights of the citizens particularly women's right.(Kakar, 2014, pp. 1-2)Afghan women are facing challenges presently after the codification of legal rights of women's participation along with the act of participation of citizens.

The female civil activists of Afghanistan write down that unfortunately have not yet witnessed a major social or political evolution. Ahmed zia Masud further stated that they were still facing ethnic disputes in Afghanistan. The political arena is still turns around tribal and ethnic allegiances. The afghan female Fawzia Koofi is contributing in law making process also headed the movement was hailed as an significant step in amalgamating the fragile gains made by afghan women and inspiring them should take part in public life. She lectured a speech in Dari by the name of wave of change, or Mawj-e-Tahawal stating that, to take Afghanistan from out of the days of darkness and bringing about change. There will be efforts in fight against gender discrimination. The efforts are made to increase the women participation in the election for representation of nation.(Behzan, 2013)Margherita Stancati in wall street journal stating thatWazhma Frogh has said that women have awareness about rights so cannot be ignored for long time. Women advocated for their rights in Kabul. Women get lot of votes in political activities.(Stancati, 2014)

\section{Afghan women's Challenges for Political Participation}

There are challenges which afghan women are particularly facing at the time of using their right of citizenship in political participation. Hindrances may come from multiple side for example in term of inadequate Education, Cultural and Structural limitations, Ideological factor, Political and Economic factor, Practise of proxy voting, Violence against women, Quota, Improper Constitutional rights, Role of Ministry of Foreign Affairs. The Afghan women are facing consequences still in the result of hardships.

The ideological factor remains effective to produce multiple challenges to afghan women and prevent them from political participation. It is discussed about patriarchy as a system of male domination that shapes relationship of women in political activities. The apparatus transforms male and female in to men and women by creating a gender hierarchy relation where men are privileged. According to Andrienne Rich, patriarchy “ A familial- social, ideological, political system in which men by force or direct pressure or through ritual, law and language, custom, etiquette, education and the division of labor, determine what part women shall or shall not play in which the female is everywhere subsumed under the male." Ideology as a tool used in 
patriarchy to keep women in their domestic work and keep them out of the political domain. In politics money is used more and more as a lot of time. Women remain afar from politics one of the main reason is the lack of proper resources to women which she utilized for different purpose in the politics at the time of political participation. But afghan women have no source of earning that is why she cannot participate it. It is another challenge which afghan women facing it can be overcomes only providing more opportunities for seeking education.(Bari, 2005, pp. 3-7)

The success of the developed country depends upon the rate of their literacy. Only those countries adapt complete democracy and follow the charter of democratic ideals where education is essential to everyone. Contrary to those nations Afghan people remain deprive from higher education. Their women's remain afar from basic education and school in the past. Presently as the result of efforts global community the awareness to seek education in afghan people incite more as compare to earlier people. According to Morgan in his article, "A crucial element in any strategy promoting social, economic, development and women's rights is education for both males and females. Also strengthening the security of the country" The progress in the field of education can be estimated through this data that six million children get admitted last year for primary education. Only one third of students approximately in grades 1-12 are girls.(Morgan, 2008, p. 5) In this women's easily understand their right as a citizen participation in politics. As the result they may able to prevent the proxy voting system and violation against women. Quota is another way to providing more opportunities to afghan women for getting participation in the legislation and affairs of the government, For example by fixing their seats in the parliament also in the house of upper and lower.

Additional social constraints have to face Afghan women that limit their ability to participate in the political process. Afghans historical social and structural norms and limitations create challenges for women. These traditional norms can produce hindrance in free and fair elections. These norms facilitate proxy voting pattern and other forms of electoral fraud. In Afghanistan the reason behind such proxy is the absence of photograph of afghan women in their id card which diminish their identity and create the chance for proxy. That is why women's are mostly predisposed to identify fake in the process of registration of vote. According to the culture of Afghanistan their women has no permission even to interact with unrelated men, including male voter registration officials. Such practices suppress women's legal right to vote, they did not cast their vote as Afghanistan Electoral Law requires because they remain dependent upon their male family members. As the result the true result of the election remains a far from the scene and the process of Proxy voting remains continue became a major challenge to afghan women.(Worden, August 11,2011, pp. 1-3)The success of 2014 elections based on the voices of the afghan women to avoid the massive fraud.(Wie, 2014, p. 5)

The social scientists describes about the afghan constitution article 22 which focus on fundamental rights and duties of citizens. It explained the citizens of Afghanistan without discrimination of women or men-have equal rights and duties before the law. Than ministry of foreign affairs have been founded for the guarantee of women's rights in result of Bonn 
accord 2001, MOWA has become a kind of internationally-instigated dumping ground for any kind of women issue.(Morgan, 2008, pp. 3-5)

The consequences which women have faced as the result of raise their voices against suppression of their right of political participation. The head of Afghanistan Independent Human Rights Commission, Sima Samar stating that Taliban tactics have specifically targeted women's specially those who have position in high ranks of government. She says that Taliban seeks to limit the active presence and activist of women from their society. Two females who are the chief executive of the Women Affairs in the province of Laghman were assassinated in the mid of the July and December of 2012. Further in August of 2013 Fariba Ahmdai one of the brave women in parliamentarian was kidnapped by Taliban militants from the province of Kandahar. Roh Guhl Khairzad's another female who was a prominent senator was also killed through ambushed her vehicle. It is clear from mentioned incidents that afghan women's faces multiple challenges not only regarding the suppression of their rights rather by made an attempt of assassination. Khairzad told the BBC that they attack women and kill them to scare other two women and discourage them from coming into politics. Presently at the time of transition of the country political destiny the government of Afghanistan, the United States of America and with other international partners must redouble their commitment and support of the women of Afghanistan.(Wie, 2014, pp. 5-7)

The coordinator of Young Women for change Noorjhan Akbar has written that women wished peace but not cost of losing freedom again. International communities should guarantee the women right beyond 2014to ensure about women's rights are not scarified. It is expected that by openly pledging at any political settlement must explicitly ensure women rights. Also ensure the women participation in all governmental institutions. "They (Women) want to move forward, they want to move, they want to participate. They want to be involved. We believe peace is not the absence of war, Peace for Afghan women is also about access to health care, educational facilities and socio economic opportunities.' United States General Kofi Annan stating; there is no tool for development more effective than empowerment of women. No other policy is as likely to raise economic productivity, or to reduce child and maternal mortality... No other policy is as powerful in increasing the chance of education for the next generation, And I would also venture that policy is more important than preventing conflict, or in achieving reconciliation after a conflict has ended.”(N.A, 2011 p.7, pp. 1-20)

\section{Conclusion}

It is concluded that in the world every community citizen has the right to participate in politics without gender discrimination. Women are more empowered in developed countries than males in the third world countries. Afghanistan is facing multiple challenges due to war of several decades. The women of Afghanistan are facing challenge to use their right to participate in elections as a candidate also preventing from casting the vote. We realise the proper status and need of afghan women at the time of hour than we must see the afghan present partial and preliminary results which possible through the massive participation of afghan women in 2014 presidential election. It is not hard to say that women's political participation remain one of the splendid symbols for putting Afghanistan on the path of 
transition and strengthens the democracy. As the result attempt of assassination, murder, violation and injustice against women may not lead in the afghan community because global communities, international organizations produce awareness for the protection and guarantee of their rights.

\section{Recommendations}

There are some recommendations for afghan women participation in politics which are as followings; the political parties give chance in organizational structure. The parties are bound for voluntary quotas. The political parties provide support and resources to ensure the maximum political participation of women in election. The effective political participation can focus on suppressed turnout and female proxy voting. The political parties developed programs to include women as candidates and also in leadership. The female member parliament conclave and female provincial council members is campaigner of reformer of electoral environment for women. regardless of their differences on specific political issues. These organizations focus for escalation of electoral participation of women regardless differences on political issue. The media can facilitate female political leadership at primary level to flourish political awareness. The media has to launch a move in masses about political participation of women in politics of Afghanistan. The media highlight significance of women participation in political system to get share in decision making of governmental affairs. The media proves helpful for overcoming traditional barriers in path of women's participation in elections. Radio is favour able for developing awareness in women for political participation. The equality of rights, the math of political advantage is the most effective incentive women's participation in Afghan elections.

\section{Bibliography}

A Place at the table: Safegaurding Women's rights in Afghanistan. (2011 p.7, October 3). Retrieved June 2014, from ttp//www.oxfam.org/sitce//www.ofam.org/ files/bp153-womens-rights-afghaistan: http//www.oxfam.org/sitce//www.ofam.org/ files/bp153-womens-rights-afghaistan

Ahmed-Ghosh, D. H. (2003). A History of Women in Afghanistan: Leson Learnt for the Future Or Yesterday and Tomorrow: Women in Afghanistan. Journal of International Women's Studies.

Bari, F. (2005). Womens Political Participation: Issues and Challenges. Thailand.

Behzan, F. (2013, October 1). Afghan Women's Enters Political Arena. Retrieved from htt:pwww.frl/afghanistan-women-political-movement-Koofi/25123703

Donati, M. H. (N.A). Releif in Afghanistan after largely peaceful landmark election. Retrieved from http://www.reuterus.com/articles/2014/04/05/us-of election

Eremenko, M. (n.d.). "Political Participation: Model by Verba in the EU and Russia. Retrieved from http//www.culturaldiplomacy.org/academy/content/pdf/participant-papers/e 


\section{Macrothink}

Journal of Public Administration and Governance ISSN 2161-7104 2014, Vol. 4, No. 3

Fahd, H. (2014, April 6). Afghanistan Presidential Election 2014. Retrieved from http://www.jinahinstitute.org/afghanistan-presidential-election-2014

Francisco O. Ramirez, Y. S. (1997). The Changing Logic Political Citizenship: Cross-National Accuisition of Women's Suffrage Rights, 1890 to 1990. American Sociological Review.

Grenfell, L. (n.d.). The Participation of Afghan Women in the Reconstruction Process. Retrieved from http:www.wcl.american.edu/hrbrief/12/1grenfelpdf

Kabir, N. A. (2012). Women's Position in Afghanistan since 9/11. University of South Australia International Centre for Muslim and non-Muslim Understanding.

Kakar, P. L. (2014, June 18). Engaging Afghan Religious Leaders for Women's Rights. United States Institue of Peace.

Manger. (2014, April 1). Afghan Women Determine to Vote in Elections. Retrieved from http://www.bakhtarnews.com-at/eng/election-93-htm.

Morgan, C. (2008). Afghanistan: The Status of Women. Parliament Information and resarch service .

N.A. (2005). Report On Women Political Participation In Afghanistan. Kabul: Open Society Institution.

N.A. (2013). Afghanistan Beyond 2014: Elections,Political Settelment ,Recommendation from Afghan Civil Society. Heinrich Boll Stiftung and center for American Progress.

N.A. (2014, April 6). Afghanistan Presidential Poll hailed as a Succes. Retrieved from http://www.bbc.com.news worldasia-26908464

Palmerless, W. (2002, March 28). The Situation of Women in Afghanistan. Retrieved from http;//2001-2009.states.gov/g/wi/9118.htm

Rahimi, W. M. (1991). Status of Women: Afghanistan. Social and Human Sciences in Asia and the Pacific.

Stancati, M. (2014, April 2). The wallstreet journal.

Teorell, J. (2006). PoliticalParticipation and three theories of democracy: A Resarch inventory and agenda. European Journal of Political Resarch.

Thomas-rutting. (2014). Afghanistan Turns a Political Corner. Afghanistan Analysis Network.

Wie, S. V. (2014). Elections in Afghanistan: What's At Stake For Women . George W Bush Institue.

Worden, N. S. (August 11,2011). Real Change for Afghan Women's Rights: Oppertunities and Challenges in the upcoming parliamentary Elections. Washingto DC: United States Institute of Peace. 